cern for the least fortunate members of the profession even while the more fortunate members of the profession fight for benefits such as maternity and paternityleave.

Answers to question 12 revealed that child care and dependent care assistance are still ideas whose time has not come for most college librarians. Since these benefits are being increasingly sought after in the corporate world, however, the availability of these benefits could increase dramatically very quickly, if colleges wish to compete for good personnel.

In tabulating answers to question 13 , the authors found that librarians had good access to education benefits. Librarians at 68 institutions could take courses during normal working hours, and only 38 respondents indicated that they could not, which left a non-response rate of 15 completed survey forms. Spousal and child education benefits were available to 78 librarians, while 10 librarians indicated that they did not enjoy these benefits, and 31 did not respond.

After completing this questionnaire and survey, the authors realized that: 1) specific mention of sabbatical eligibility should have been made in question 8 , and 2) spousal and child education benefits should have been separated.

In summation, the authors conclude that most college librarians enjoy employee benefits standard in the corporate world and that vacation and tuition benefits are a big plus for academic librarians. We are, however, concerned that most college librarians lack standard benefits enjoyed by teaching faculty even though our credentials are gradually becoming equivalent, and some of these benefits may be needed to undergo the constant professional updating librarians need today, whether or not they have or desire faculty status.

\title{
Time grants
}

\section{By Cynthia Stewart Kaag and Nancy Shepard}

\author{
Reference Librarians, Owen Science and Engineering Library \\ Washington State University
}

\section{Resource sharing where the resource is time.}

\section{$\mathbf{0}$}

ne of the eternal questions faced by academic librarians in tenure-track positions is where to find time to do the research and writing necessary for promotion and tenure. There is only so much reorganizing, reallocating and rethinking of priorities that can be done before we all come to the same point: too much to do, not enough time.

During a retreat set up to re-evaluate our goals and objectives, the faculty at the Owen Science and Engineering Library at Washington State University came up with a plan that would allow individual librarians time off from reference desk responsi- bilities for the purpose of working on special projects. Originally, the idea came in the form of a preretreat proposal by one of the librarians for release time to pursue scholarly and professional activities. This was broadened to make possible grants of time for all librarians as needed for particular projects.

As hammered out during the retreat, those librarians who had projects they wished to undertake or complete submitted written proposals which were reviewed by all reference librarians and then discussed at a faculty meeting. The head of reference determined how many hours might be avail- 


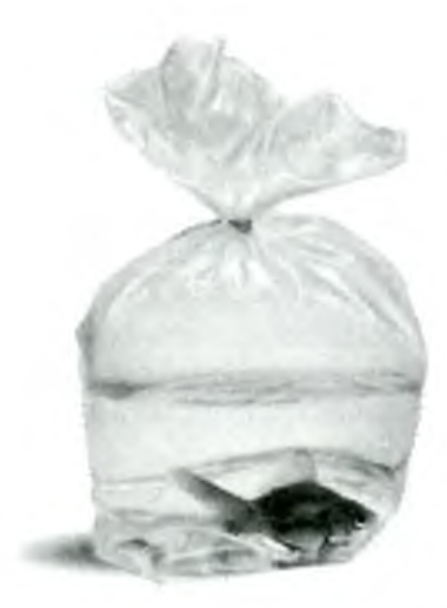

The small customer.

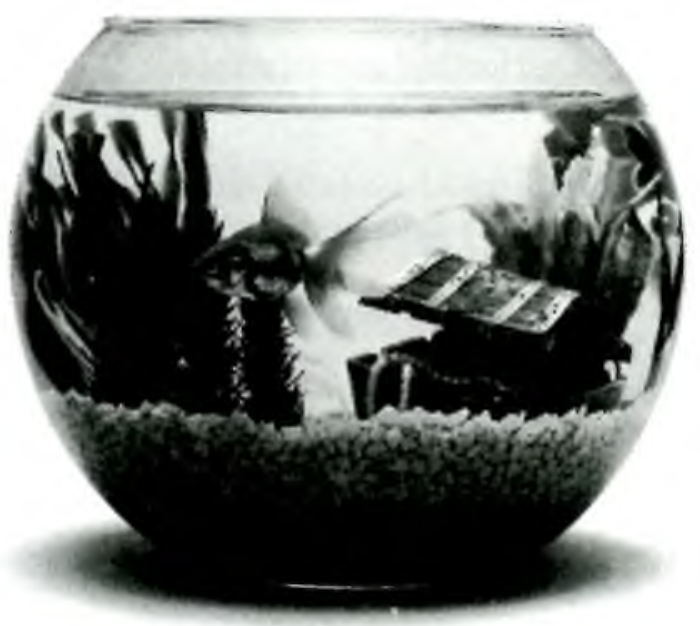

The small customer at Ballen.
With some booksellers, a small customer doesn't rate quite the consideration that a large customer might. But at Ballen, the single book customer receives the same service and services that a thousand book customer does.

Which means no matter what size your library, you can expect to have your very own customer service representative to help answer all your questions. And your very own shelf reserved in our warehouse to guard against shipment and inventory mix-ups.

It also means access to our online, interactive BallenNet system for order entry and current status. The ability to reach a Ballen company officer just by picking up the phone. And an ongoing evaluation of library needs so rigorous, it's given us the industry's lowest overall return rate - less than $1 \%$.

All of which we provide with the understanding that what are small fish today, might one day be big ones.

For information or our new brochure, call (800)645-5237.

In New York, call (800)832-4552.

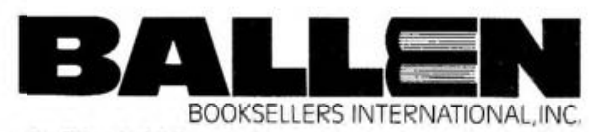

125 Ricefield Lane, Hauppauge, New York 11788 
able for time grant purposes if double staffing of the reference desk during slack times were eliminated. (Extra staffing during those times is now provided on an on-call basis.) In an open give-and-take discussion the reference librarians determined who should receive the grants and how many hours would be granted. The Science and Engineering Library faculty have a strong sense of collegiality and are very committed to supporting both coworkers, professional development and patron needs. This atmosphere is necessary in order to make a time grant system work.

Projects proposed for time grants included:

1) development of an online full-text article delivery service;

2) investigation of the long-term effect of freshman bibliographic instruction on retention and graduation rates;

3) write-up of article on innovative library promotion efforts;

4) preparation of a videotape on library research for upper-level engineering classes;

5) preparation of a seminar series to promote online services available in WSU Libraries;

6) improved access to in-house information files, including learning about dBase III + and other computer software to produce indexes;

7) qualitative evaluation of reference skills through taped patron-librarian transactions.

During the first round of time grants, total hours per week available were 12 (though we feel that even two hours perweek would be enough to start a time grant program). Librarians on time grants received between two and four hours per week for periods ranging from one week to two months. It was decided that, in some cases, complete elimination of reference duty for individuals would be acceptable for short periods of time. A written statement of progress was submitted at the end of the grant period.

Results of the first round of time grants included completion of the reference evaluation, expanded promotion of library services, and the implementation of the full-text article delivery project. A major benefit for several participants was learning to set aside blocks of time for work on a project, rather than letting small daily tasks eat up all one's time. Nearly all the science librarians have received time grants and a second round is underway.

There have been changes in this second round, both in procedures and types of projects. The application process is much more casual, and the discussion of time allocation took all of 15 minutes. By general agreement, one librarian who had been appointed to a short-term, time-intensive committee was granted time to allow her to attend meetings and do the necessary background reading. $\mathrm{A}$ large project completed under the second round was compilation of files of user education materi- als, both generic and course-specific, which can be used by any librarian for BI material preparation and class presentations.

Points to consider in starting a time grant program include: How much time can be made available? Where does it come from? Who gets it? How much? Who decides? Should there be an evaluation of results, and who will do it? Will time grants be short term or long? Will the grant program operate year round or only during certain times? How are time grants good for patrons, as well as for librarians, professional development?

Knowing time may be available encourages development of a wider variety of projects beneficial to the library. Knowing colleagues may be assuming extra duties during a personal time grant is an encouragement for efficient use of time. Having a time limit to work on a project provides incentive for completion. Time grants have proved a simple and effective way to encourage scholarly and professional research and publishing and to offer the library and its patrons both immediate and long term benefits.

Author's note: This article was begun using a twoperson, two-hourtime grant.

\section{Conference on Integrated Online Library Systems}

The fifth national Conference on Integrated Online Library Systems (IOLS '90) will be held May 2-3, 1990, at the Sheraton Centre Hotel, New York. Contributed papers are sought from all types of libraries on any aspect of online library systems. The conference theme is "Converging Functions, Diverging Technologies, Growing Options."

Some of the topics expected to be addressed include: evaluating and selecting library systems; integration of library records and text retrieval; diverse linked systems; database management systems as online catalogs; networking; ergonomics; data conversion; system upgrading and migrating; and service contracts.

All papers will be evaluated and selected by the IOLS Program/Review Committee, which consists of Brian Alley (Sangamon State University), Sharron Carlson (Case Western Reserve University), Lynn Heer (NASA), and Judy McQueen (library consultant). All accepted papers will be published in the conference proceedings.

Address all inquiries and contributed papers to: David C. Genaway, Chair, IOLS' 89 Review Committee, c/o Genaway Associates, Inc., P.O. Box 477, Canfield, $\mathrm{OH} 44406-0477$. 